\title{
Occupational exposure to metals among blacksmiths in Kano Metropolis, Nigeria
}

\author{
Ibrahim Lawal Abdullahi* $^{*}$, Ali Sani $^{\circledR}$, Bilkisu Aminu Jibril ${ }^{\circledR}$ \\ Department of Biological Sciences, Bayero University, Kano, Nigeria
}

\begin{abstract}
Background: Occupational workers especially those working in industries associated with metal and mining activities are excessively exposed to many toxic metals, which affect them. This study was conducted to determine the metal concentrations in body fluids of blacksmiths exposed to metals. Methods: The present study was conducted on a total of 140 male blacksmiths and 120 male controls in Kano Metropolis, Nigeria. All information related to working conditions such as duration of engagement and use of personal protective equipment (PPE), health history, life style, etc. were obtained using an interview questionnaire. Blood samples were also collected, digested, and subsequently, subjected to flame atomic absorption spectrometric (FAAS) analysis to determine the heavy metals concentration in the samples.

Results: Exposure to heavy metals led to various degrees of health complications including headache (68\%), fever (52\%), chest pain (44\%), itching (43\%), irritation (35\%), shortness of breath (31\%), and coughing (27\%). Meanwhile, the concentration of blood heavy metals of $\mathrm{Pb}, \mathrm{Cd}, \mathrm{Cr}$, and $\mathrm{Zn}$ was 0.17 , $0.076,0.24,4.50 \mu \mathrm{g} / \mathrm{mL}$, respectively. The values were above the permissible limits of the American Conference of Governmental Industrial Hygienists (ACGIH) and significantly differ from those in controls $(P<0.05)$, which was directly proportional to age and exposure rates.

Conclusion: According to the results, blacksmithing is an occupation with health hazards, which affect blood metals levels, and subsequently, lead to serious health complications.

Keywords: Humans, Heavy metals, Occupation, Questionnaires

Citation: Abdullahi IL, Sani A, Jibril BA. Occupational exposure to metals among blacksmiths in Kano Metropolis, Nigeria. Environmental Health Engineering and Management Journal 2020; 7(2): 135-141. doi: 10.34172/EHEM.2020.16.
\end{abstract}

Article History:

Received: 8 May 2020

Accepted: 17 July 2020

ePublished: 2 August 2020
*Correspondence to:
Ibrahim Lawal Abdullahi
Email:
ilabdullahi2013@gmail.com

\section{Introduction}

Modern industrialization has led to various types of environmental pollution including air, soil and water pollution, which has adverse health effects on living organisms such as humans. The major human health risks are caused by exposure to heavy metals such as lead $(\mathrm{Pb})$, cadmium $(\mathrm{Cd})$, arsenic (As), and mercury $(\mathrm{Hg})$ are increasing in some parts of the world. However, compared to less-developed countries, industrial processes have declined in most developed countries over the last 100 years (1). Male and female workers especially adults working in industries such as metal and mining industries are excessively exposed to many toxic metals and affected by them through inhalation.

Kano is the second most populated state in Nigeria with a population about 14 million people. It is known as the centre of commerce because of the major commercial activities in the state. Some of the manufactured goods are produced locally by artisans who constitute a variety of occupations such as carpentry, dyeing, blacksmithing, weaving, etc. Blacksmithing is one of the traditional industries which thrive on the discovery and mining of iron ore as well as on its local metal-smelting process. Iron technology was imbedded in the ways of life of ancient Africans (2). Blacksmithing is a common activity and seen to be a family-based occupation. It is mainly transforming metals through heat. The process includes welding, cutting, grinding, shaping, bending, painting, and forging (3).

Most individuals engaged are exposed to different types of undue stress caused by noise, high heat, muscle cramps, heavy metals exposure, metallic sparks, etc. Not only occupational workers but also non-occupational workers may be exposed to high metals in the environment. Exposure to such heavy metals is a great global concern for workers health because it has drastically increased over the past decades as a result of high demand for different industrial products which are produced through dyeing, 
metal refining, and plastic moulding. Occupational exposure to heavy metals such as $\mathrm{Cd}, \mathrm{Cr}$, and $\mathrm{Pb}$ has been associated with the development of cancer, poor reproductive health, neurological disorders, etc.

Generally, polluted environment has probably had a significant impact on the levels of heavy metals in blood of Nigerians. However, there is no definitive risk factor that can be presented (4).

Alli reported that the blood levels of $\mathrm{Cd}$ and $\mathrm{Pb}$ in occupationally exposed and non-exposed subjects were above the permissible range of $0.03-0.12 \mu \mathrm{g} / \mathrm{dL}$ for $\mathrm{Cd}$ and $0-10 \mu \mathrm{g} / \mathrm{dL}$ for $\mathrm{Pb}$, which could be a potential health hazard (5). Another study by Musa et al indicated that the concentrations of $\mathrm{Cd}$ and $\mathrm{Zn}$ in the population in Zaria, North-western Nigeria, was within the permissible limit. However, occupationally exposed individuals had significantly higher concentrations of the metals (6).

Tilako et al also reported that individuals who were occupationally and environmentally exposed to zinc had mean blood-Pb levels of 42.30 and $28.67 \mu \mathrm{g} / \mathrm{dL}$, respectively, which were significantly higher than those in control group $(P<0.0001)(7)$.

Most importantly, occupational health in Kano has been given little or no attention by stakeholders. As such many diseases and disorders might be due to exposure to toxic compounds in occupational environment. These exposures might pose and increase the occupational health risks, which can be manifested in the levels of metals in the body's systems. Hence, it is important to determine the metals concentrations in the body of industrial workers to monitor and assess their impact on their health $(8,9)$.

The present study was conducted to determine the metals concentrations in the blood of blacksmiths working in Kano Metropolis, Nigeria.

\section{Materials and Methods}

Reagents and chemicals

Nitric acid of analytical grade (65\%, Sigma Aldrich) and perchloric acid (70\%, Sigma Aldrich) were used for sample preparation. Standard solutions for calibration of $\mathrm{Pb}, \mathrm{Cr}$, $\mathrm{Cd}$, and $\mathrm{Zn}$ were prepared from $1000 \mathrm{mg} / \mathrm{L}$ standard stock solution of GFS Fishers' AAS Reference Standard. All the solutions were prepared in deionized water. A dilution correction was applied for samples diluted or concentrated during analysis (10).

\section{Subjects and study design}

The sampling sites were Gabasawa and Nassarawa, which are located in Kano State, Nigeria. In this cross-sectional study, a total of 260 blood samples were collected. After obtaining the consent of participants, 140 blood samples were obtained from blacksmiths randomly from the sampling sites. However, 120 blood samples were collected from control groups that have no records or history of involvement in blacksmithing or blacksmithing-related occupations. All blacksmiths were included irrespective of age or gender as inclusion criteria and those who had occupations other than blacksmithing were excluded. The study was conducted from April to August 2018 (11).

A structured and standard interview was conducted to obtain information including age, gender, life style (smoking and alcohol intake), qualification, duration and extent of engagement in the occupation, daily working hours, use of personal protective equipment (PPE), medical complications etc, from the blacksmiths and controls (12).

Ethical approval for the study was obtained from the Kano State Ministry of Health. Consent of the participants was equally obtained ensuring them about confidentiality of data and privacy of individuals (MOH/Off/797/T.I./90).

\section{Measurements of heavy metals}

Blood samples $(5 \mathrm{~mL})$ were collected from the respondents through venipuncture using a phlebotomy needle into an EDTA container by a certified technician in the field and stored at $4{ }^{\circ} \mathrm{C}$. Glassware and plastics were washed, rinsed many times with tap water, and then, soaked in 5\% $\mathrm{HNO}_{3}$ solution for 24 hours. They were then rinsed with deionized water. Afterwards, $5 \mathrm{~mL}$ of the sample and the mixture of nitric acid (65\%) and perchloric acid (70\%) at the ratio of $4: 1$ were transferred into a $125 \mathrm{~mL}$ pressureresistant bottle. The samples were digested for 4 minutes at $300 \mathrm{~W}$. The digestion was stopped when a colourless solution was obtained, and then, it was evaporated to dryness. The solution was diluted to $25.0 \mathrm{ml}$ with deionised water. The solutions were cooled, filtered by Whatman No. 42 filter into a 100-mL calibrated flask, and diluted up to the mark. The sample solution was analyzed for $\mathrm{Cd}, \mathrm{Cr}, \mathrm{Pb}$, and $\mathrm{Zn}$ using flame atomic absorption spectrophotometer (210 VGP Atomic Absorption Spectrophotometer, BUCK SCIENTIFIC, East Norwalk, USA) (10). The working conditions and parameters of the instruments are presented in Table 1.

Stock solutions were serially diluted to give concentrations as shown below:

- Cd: A calibration curve with different cadmium concentrations $(0,0.1,0.3$, and $0.5 \mathrm{mg} / \mathrm{L})$ was prepared.

- Cr: A calibration curve with different chromium concentrations $(0,0.03,0.05$, and $0.1 \mathrm{mg} / \mathrm{L})$ was prepared.

- Pb: A calibration curve with different lead concentrations $(0,0.1,0.2$, and $0.3 \mathrm{mg} / \mathrm{L})$ was prepared.

- Zn: A calibration curve with different zinc concentrations $(0,2,4$, and $6 \mathrm{mg} / \mathrm{L})$ was prepared.

Data quality assurance/quality control (QA/QC)

Method validation was performed by assessing several analytical figures of merit namely: linearity and range, precision, limit of detection, limit of quantification, and accuracy (13-15). 
Table 1. Working conditions for determining the concentration of some heavy metals using atomic absorption spectrophotometer

\begin{tabular}{lcccccc}
\hline Metals & Wavelength $(\mathrm{nm})$ & Slit Width $(\mathrm{nm})$ & Detection Limit $(\mathrm{mg} / \mathrm{L})$ & Lamp Current $(\mathrm{mA})$ & Linear Range $(\mathrm{mg} / \mathrm{L})$ & Flame Type $($ Color) \\
\hline $\mathrm{Zn}$ & 213.9 & 0.7 & 0.05 & 6.5 & 2.50 & A-A, lean/blue \\
$\mathrm{Cd}$ & 228.80 & 0.7 & 0.01 & 2 & 2.00 & A-A, lean/blue \\
$\mathrm{Cr}$ & 357.90 & 0.7 & 0.04 & 2 & 5.00 & A-A, rich/yellow \\
$\mathrm{Pb}$ & 283.30 & 0.7 & 0.08 & 5 & 20.00 & A-A, lean/blue \\
\hline
\end{tabular}

The precision was measured as relative standard deviation of the concentration in the study (14). The measurements were done under conditions of repeatability and intermediate precision (13).

The accuracy was determined by calculating recoveries of $\mathrm{Cd}, \mathrm{Cr}, \mathrm{Pb}$, and $\mathrm{Zn}$. According to $\mathrm{ICH}$, the recoveries were determined by spiking technique (13). All analytical steps were performed in three replicates with three different concentrations of $\mathrm{Cd}, \mathrm{Cr}, \mathrm{Pb}$, and $\mathrm{Zn}$ (15).

\section{Statistical analysis}

Data were analyzed using SigmaStat 3.5 statistical software. The results were expressed as a mean \pm standard error. The differences between groups were determined using ANOVA considering significance level of $5 \%$.

\section{Results}

Table 2 shows the demographic information of blacksmiths. Subjects who did not report alcohol consumption but had a history of cigarette smoking were included in control group.

The respondents reported health complications including headache, fever, chest pain, itching, dizziness, irritation, shortness of breath, and coughing with high number of reported cases in decreasing order of frequency (Table 3). However, eye problems, haematuria, and anxiety were reported to a lesser extent and only $11 \%$ reported no symptom at all. Control group did not report any related symptoms at all.

The concentrations of all the metals analyzed (Table 4) were above the limit reported by the American Conference of Governmental Industrial Hygienists (ACGIH). Similarly, the concentrations of metals increased with age, in other words, the higher the age of individuals, the higher the concentrations of metals. Moreover, there was a statistically significant difference in the concentration of $\mathrm{Cd}$ and $\mathrm{Pb}$ between the age groups $(P<0.05)$. However, there was no significant difference in the concentration of $\mathrm{Cr}$ and $\mathrm{Zn}$ between the age groups $(P>0.05)$.

The concentrations of all the metals analyzed (Table 5) were above the limit of the ACGIH. Similarly, the concentrations of metals increased with age, in other words, the higher the age of individuals, the higher the concentrations of metals. Additionally, there was a statistically significant difference in the concentration of $\mathrm{Cd}, \mathrm{Pb}$, and $\mathrm{Zn}$ between the age groups $(P<0.05)$. However, there was no significant difference in the concentration of Cr between the age groups $(P>0.05)$.

The concentrations of all the metals analyzed (Table 6) were above the limit reported by the ACGIH. Moreover,

Table 2. Demographic information of blacksmiths in Kano Metropolis

\begin{tabular}{|c|c|c|}
\hline Characteristics & $\begin{array}{l}\text { Blacksmiths } \\
(n=140)\end{array}$ & $\begin{array}{l}\text { Controls } \\
(n=120)\end{array}$ \\
\hline Age (y) & $45.5 \pm 16.2$ & $40.2 \pm 11.8$ \\
\hline Exposure (y) & $26.3 \pm 2.8$ & - \\
\hline Gender & Male (100\%) & Male $(100 \%)$ \\
\hline Daily contact (h) & $5 \pm 3$ & - \\
\hline \multicolumn{3}{|l|}{ PPE } \\
\hline Used & $6 \%$ & - \\
\hline Not used & $94 \%$ & - \\
\hline \multicolumn{3}{|l|}{ Educational qualification } \\
\hline Primary & $64 \%$ & $55 \%$ \\
\hline Secondary & $33 \%$ & $25 \%$ \\
\hline Tertiary & $3 \%$ & $20 \%$ \\
\hline \multicolumn{3}{|c|}{ Awareness of health hazards } \\
\hline Yes & $39 \%$ & - \\
\hline No & $52 \%$ & - \\
\hline Maybe & $9 \%$ & - \\
\hline \multicolumn{3}{|l|}{ Life style } \\
\hline Alcohol consumption & $0 \%$ & $0 \%$ \\
\hline Cigarette smoking & $57 \%$ & $46 \%$ \\
\hline
\end{tabular}

Table 3. Health complications and hazards experienced by blacksmiths in Kano Metropolis $(\mathrm{N}=140)$

\begin{tabular}{lc}
\hline Medical Complications & Frequency (\%) \\
\hline Shortness of breath & 31 \\
Headache & 68 \\
Itching & 43 \\
Haematuria & 10 \\
Fever & 52 \\
Irritation & 35 \\
Cough & 27 \\
Chest pain & 44 \\
Dizziness & 39 \\
Anxiety & 9 \\
Eye problems & 13 \\
Asymptomatic & 11 \\
\hline
\end{tabular}


Table 4. Mean blood concentration $(\mu \mathrm{g} / \mathrm{mL})$ of heavy metals among various age groups of blacksmiths in Kano Metropolis, 2018

\begin{tabular}{lccc}
\hline Age Group $(\mathrm{y})$ & $\mathrm{Cd}(\mu \mathrm{g} / \mathrm{mL})$ & $\mathrm{Cr}(\mu \mathrm{g} / \mathrm{mL})$ & $\mathrm{Pb}(\mu \mathrm{g} / \mathrm{mL})$ \\
\hline $15-25(\mathrm{n}=30)$ & $0.086 \pm 0.009$ & $0.066 \pm 0.008$ & $0.198 \pm 0.023$ \\
$26-35(\mathrm{n}=43)$ & $0.105 \pm 0.103$ & $0.075 \pm 0.005$ & $0.231 \pm 0.029$ \\
$36-45(\mathrm{n}=48)$ & $0.203 \pm 0.004$ & $0.074 \pm 0.009$ & $0.253 \pm 0.031$ \\
$>45(\mathrm{n}=19)$ & $0.285 \pm 0.005$ & $0.089 \pm 0.006$ & $0.261 \pm 0.010$ \\
ACGIH (2008) & 0.005 & 0.0025 & 0.05 \\
$P$ value & $<0.05$ & $>0.05$ & $<.43 \pm 0.524$ \\
\hline
\end{tabular}

*Values are expressed as mean $\pm \mathrm{SEM}, \mathrm{N}=140$

Table 5. Mean blood concentration $(\mu \mathrm{g} / \mathrm{mL})$ of heavy metals among blacksmiths at different exposure rates in Kano Metropolis, 2018.

\begin{tabular}{|c|c|c|c|c|}
\hline Exposure Duration (y) & $\mathrm{Cd}(\mu \mathrm{g} / \mathrm{mL})$ & $\mathrm{Cr}(\mu \mathrm{g} / \mathrm{mL})$ & $\mathrm{Pb}(\mu \mathrm{g} / \mathrm{mL})$ & $\mathrm{Zn}(\mu \mathrm{g} / \mathrm{mL})$ \\
\hline $5-10(n=26)$ & $0.085 \pm 0.008$ & $0.069 \pm 0.007$ & $0.177 \pm 0.082$ & $3.45 \pm 0.587$ \\
\hline $11-20(n=49)$ & $0.140 \pm 0.007$ & $0.072 \pm 0.005$ & $0.208 \pm 0.129$ & $3.76 \pm 0.446$ \\
\hline $21-30(n=42)$ & $0.192 \pm 0.009$ & $0.072 \pm 0.011$ & $0.229 \pm 0.027$ & $4.09 \pm 0.687$ \\
\hline $31-40(n=23)$ & $0.276 \pm 0.009$ & $0.08 \pm 0.007$ & $0.255 \pm 0.006$ & $4.51 \pm 0.875$ \\
\hline ACGIH (2008) & 0.005 & 0.0025 & 0.05 & - \\
\hline$P$ value & $<0.05$ & $>0.05$ & $<0.05$ & $<0.05$ \\
\hline
\end{tabular}

*Values are expressed as mean \pm SEM, $\mathrm{N}=140$

Table 6. Mean blood concentration $(\mu \mathrm{g} / \mathrm{mL})$ of heavy metals among various age groups of control groups in Kano Metropolis, 2018

\begin{tabular}{|c|c|c|c|c|}
\hline Age Group (v) & $\mathrm{Cd}(\mu \mathrm{g} / \mathrm{mL})$ & $\mathrm{Cr}(\mu \mathrm{g} / \mathrm{mL})$ & $\mathrm{Pb}(\mu \mathrm{g} / \mathrm{mL})$ & $\mathrm{Zn}(\mu \mathrm{g} / \mathrm{mL})$ \\
\hline $15-25(n=20)$ & $0.067 \pm 0.003$ & $0.062 \pm 0.004$ & $0.144 \pm 0.009$ & $2.09 \pm 0.22$ \\
\hline $26-35(n=54)$ & $0.065 \pm 0.008$ & $0.067 \pm 0.007$ & $0.139 \pm 0.01$ & $1.35 \pm 0.42$ \\
\hline $36-45(n=33)$ & $0.088 \pm 0.006$ & $0.061 \pm 0.006$ & $0.149 \pm 0.02$ & $1.83 \pm 0.36$ \\
\hline$>45(n=13)$ & $0.134 \pm 0.005$ & $0.077 \pm 0.005$ & $0.135 \pm 0.01$ & $1.95 \pm 0.50$ \\
\hline ACGIH (2008) & 0.005 & 0.0025 & 0.05 & - \\
\hline$P$ value & $>0.05$ & $>0.05$ & $>0.05$ & $>0.05$ \\
\hline
\end{tabular}

*Values are expressed as mean $\pm \mathrm{SEM}, \mathrm{N}=120$

there was no statistically significant difference in the concentration of all metals between the age groups $(P>0.05)$.

\section{Discussion}

Demographic information of the respondents presented in Table 2 shows that the majority of blacksmiths in Kano Metropolis, spend considerable proportion of their lifetime in the occupation and do not use any form of PPE. Long-time exposure of blacksmiths to heavy metals recorded in the present study makes them prone and exposed to all kinds of risks, which may arise from extensive participation in the occupation. Such problems coupled with the fact that many of them are unaware of the risks and potential dangers associated with the occupation, which subsequently, increases health risk among them. Lack of profound knowledge and awareness is obvious which might have been a contributing factor in excessive exposure regimes. Poor knowledge of the adverse health hazards related to such occupations has been found to be related to the low level of education. Probably because education makes people aware of the various health hazards and their associated causes as stated by Agbana et al (16). Similarly, there were elevated blood levels of $\mathrm{Hg}$ and $\mathrm{Pb}$ among the artisans. This could possibly be attributed to work environment, harmful effects of $\mathrm{Hg}$ and $\mathrm{Pb}$, lack of awareness of workplace safety and the need to use PPEs (17). Furthermore, implementation of regular vocational training could reduce the burden of the disease associated with metal work apprentices (18).

The effects of such exposure to metals have been observed in some related health complication as presented in Table 3. Such problems include headache, chest pain, itching, and fever were observed among other symptoms compared to the control group that reported no related symptom. Some studies have reported adverse health effects among workers which were primarily recognized in various forms of neuropsychological disorders (1921). Some studies also reported reduced olfactory and visionary capabilities (22-24). Similarly, other symptoms such as coughing, breathing difficulties, chest tightness, and wheezing were reported by Bepko and Mansalis, as 
occupational health hazards-related symptoms, which are among the signs observed among blacksmiths in the present study (25).

The concentrations of all four metals ( $\mathrm{Zn}, \mathrm{Pb}, \mathrm{Cd}$, and $\mathrm{Cr}$ ) analyzed in this study are presented in Tables 4 to 6 . Among metals, $\mathrm{Zn}$ has the highest concentration while $\mathrm{Cr}$ has the least one. The metals concentrations had a descending order of concentration as follows: $\mathrm{Zn}>\mathrm{Pb}>\mathrm{Cd}>\mathrm{Cr}$. Similarly, in a study by Sani and Abdullahi, the order of heavy metals concentrations in blood was reported as $\mathrm{Pb}>\mathrm{Cr}>\mathrm{Cd}$ (12). The concentrations of all metals were higher than the limit reported by the ACGIH (26). The metals concentration increased with increase in age and exposure rates and were found to be statistically different between blacksmiths and control $(P<0.05)$. Furthermore, the concentrations of all metals in control group were lower than those in blacksmiths (Table 6). This might be related to the working conditions and exposure regimes, which coupled with reported symptoms give more chance for metals poisoning. There was no significant relationship between cigarette smoking and alcohol consumption with metals concentration in blacksmiths $(P>0.05)$.

The mean levels of the metals in workers exposed to metals were higher than those in the control group, which is consistent with the results of several studies (27-31).High concentrations of $\mathrm{Pb}$ and $\mathrm{Mn}(1100$ and $1938 \mu \mathrm{g} / \mathrm{mL})$ were found in the blood samples of E-scavenger workers, while the concentrations of $\mathrm{Zn}$ and $\mathrm{Cu}(12615$ and $3385 \mu \mathrm{g} / \mathrm{m})$ was low (32). The geometric mean of blood levels of $\mathrm{Mn}$ was higher than the suggested normal range of 80100$99800 \mu \mathrm{g} / \mathrm{mL}$ in an Italian population. E-waste scavengers had high levels of $\mathrm{Mn}$ in their blood, therefore, they might be affected by neuro-generative disorders and diseases as observed in a study by Crossgrove and Zheng (33).

In addition, samples of toenails were reported to have significantly higher levels of Mn (median $5.8 \mu \mathrm{g} / \mathrm{g}$ ) and $\mathrm{Pb}$ (median $0.98 \mu \mathrm{g} / \mathrm{g}$ ) than those reported in more developed countries, which are comparable to those in other lowmiddle income countries. The extent of exposure to environmental disasters has caused an increased risks for many diseases previously associated with heavy metals exposure (34).

Blood $\mathrm{Pb}$ levels in children were reported as $>1000$ or $>2000 \mu \mathrm{g} / \mathrm{mL}$ and $4850 \pm 908 \mu \mathrm{g} / \mathrm{mL}$ in other studies $(35,36)$. Blood $\mathrm{Pb}$ levels in male auto mechanics (aged 18-45 years) exposed to metals in Abeokuta, Southwest Nigeria, were reported $2700-4890 \mu \mathrm{g} / \mathrm{mL}$ by Ademuyiwa et al and $3900 \pm 400 \mu \mathrm{g} / \mathrm{mL}$ by Orisakwe et al $(37,38)$. $\mathrm{The} \mathrm{Pb}$ levels reported were lower than those reported in this study for blacksmiths, and possibly because the occupation handles and generates metals.

However, blood $\mathrm{Pb}$ levels for the same age groups of nonexposed male control subjects was reported $5000 \mu \mathrm{g} / \mathrm{mL}$ by Babalola et al, $1578 \mu \mathrm{g} / \mathrm{mL}$ by Ademuyiwa et al, and $17.00 \pm 4.00 \mu \mathrm{g} / \mathrm{dL}$ by Orisakwe et al (36-38).

Blood $\mathrm{Pb}$ levels in traffic wardens and police officers from Oshodi, Dopemu, and Ojota in Southwest Nigeria were $152.42,148.56$, and $122.6 \mu \mathrm{g} / \mathrm{mL}$, respectively (39). Higher blood Mn levels can result in the Parkinson-like diseases. However, blood Mn levels are not usually reliable indicators of toxicity because they are quickly metabolized in the body. The concentrations of heavy metals in the present study indicate that continuous exposure could lead to high-risk of neurological disorders. The low blood Zn level found in the blood of E-scavengers could result in growth retardation, anorexia, delayed sexual maturation, mental retardation, and impaired immunological function (32).

In addition, higher $\mathrm{Pb}$ and $\mathrm{Ni}$ concentrations were found in blood and urine samples of welders compared to the control workers, which are consistent with the results of other studies that reported higher concentrations of $\mathrm{Cd}$, $\mathrm{Co}, \mathrm{Ni}$, and $\mathrm{Pb}$ in the blood of welders compared to those in the control group $(40,41)$.

Similarly, Sani and Abdullahi, reported higher concentrations of $\mathrm{Pb}$ and $\mathrm{Cr}$ in blood samples of metal workers. The concentrations of $\mathrm{Cd}$ and $\mathrm{Pb}$ in blood samples were found to be slightly above the recommended limits and associated with the exposure period (12). This shows that the inhalation of metal fumes in industrial settings can cause various adverse health problems (42). It has been reported that the long-term exposure of workers to metals can influence the concentrations of $\mathrm{Cd}$ and $\mathrm{Pb}$ in blood and their accumulation in the body could also be due to inadequate and poor practices and preventive mechanisms of exposure (43). Sani and Abdullahi stated that the metalworkers in urban Kano have various metals concentrations in their urine and blood, which also exceeded the minimum biological limits set by the ACGIH. They also found that age and exposure duration had an important role in metal contamination $(12,26)$. These results were confirmed by the present study, as higher concentrations of metals were observed at higher exposure rates when compared to controls and associated with improper protective measures. Workers in the chromium-related places of work could be exposed to $\mathrm{Cr}$ in 2 orders of magnitude higher than the general population (44). Detrimental impacts of such exposure may be respiratory, immunological, gastrointestinal, haematological, reproductive, and developmental. Similarly, direct contact can lead to dermal and eyes irritation. In the present study, blacksmiths depict higher levels of $\mathrm{Cr}$ and symptoms such as itching and irritation as reported by the workers during the course of the interview. In addition, exposure to $\mathrm{Cr}$ has also been associated with increased risk of respiratory system cancers, primarily lung and nasal cancer (44).

\section{Conclusion}

According to the results, blacksmiths are prone to health risks and hazards associated with the occupation based on the duration of engagement and working conditions 
which could include the absence of structural occupational hygiene measures. These practices led to various degrees of health complications including headache, fever, itching, irritation, coughing, chest pain, and dizziness to a large extent in blacksmiths when compared to controls. The blood levels of metals $(\mathrm{Pb}, \mathrm{Cd}, \mathrm{Cr}$, and $\mathrm{Zn}$ ) were above the permissible limits and those in the control, which was directly proportional to age and exposure rates. These facts demonstrate that blacksmithing is an occupation associated with adverse health hazards which affect blood metals levels, and subsequently, lead to serious health problems. Therefore, raising public awareness on the importance of the use of PPE in all occupations and regulation of the extent of engagement in occupations are recommended.

\section{Acknowledgements}

The authors would like to express their profound gratitude to the Department of Biological Sciences, Bayero University, Kano, for supporting this study.

\section{Ethical issues}

The authors certify that the data collected during the study are as stated in the manuscript, and no data from the study has been or will be published separated elsewhere.

\section{Competing interests}

The authors declare that they have no conflict of interests.

\section{Authors' contributions}

The authors all contributed and involved actively in the problem analysis, experiments design and execution, data collection and analysis, manuscript preparation and approval.

\section{References}

1. Järup L. Hazards of heavy metal contamination. British Medical Bulletin 2003; 68(1): 167-82. doi: 10.1093/bmb/ $\operatorname{ldg} 032$.

2. Neaher NC. Awka who travel: itinerant metalsmiths of southern Nigeria. Africa 1979; 49(4): 352-66. doi: $10.2307 / 1159223$.

3. Ibhadode AO. Introduction to Manufacturing Technology. Benin City: Ambik Press; 2001. p. 1-5.

4. Ibeto CN, Okoye CO. High levels of heavy metals in blood of the urban population in Nigeria. Res J Environ Sci 2010; 4(4): 371-382. doi: 10.3923/rjes.2010.371.382.

5. Alli LA. Blood level of cadmium and lead in occupationally exposed persons in Gwagwalada, Abuja, Nigeria. Interdiscip Toxicol 2015; 8(3): 146-50. doi: 10.1515/intox-2015-0022.

6. Musa A, Garba M, Yakasai IA, Odunola MT. Determination of Blood levels of cadmium and zinc in humans from Zaria, Nigeria. New Clues in Sciences 2011; 2: 49-54.

7. Tilako BH, Otuu FC, Bassey BE, Shu EN. Blood-lead levels among inhabitants of Enyigba lead-zinc mining community of Ebonyi State, Nigeria: indications of occupational and environmental health hazards. Adv Clin Toxicol 2019; 4(3): 000162. doi: $10.23880 /$ act-16000162.
8. Satake M, Mido Y, Yasuhisa H, Taguchi S, Sethi MS, Iqbal SA. Environmental Toxicology. New Delhi: Discovery Publishing House; 1997.

9. Nath R. Health and Disease Role of Micronutrients and Trace Elements: Recent Advances in the Assessment of Micronutrients and Trace Elements Deficiency in Humans. New Delhi: APH Publishing Corporation; 2000.

10. Sani A, Gaya MB, Abubakar FA. Determination of some heavy metals in selected cosmetic products sold in kano metropolis, Nigeria. Toxicology Reports 2016; 3: 866-9. doi: 10.1016/j.toxrep.2016.11.001.

11. Ebrahim GY, Sullivan KR. Sample Size in Research Methods. London, UK: Book Aid International; 2008.

12. Sani A, Abdullahi IL. Evaluation of some heavy metals concentration in body fluids of metal workers in Kano metropolis, Nigeria. Toxicology Reports 2017; 4: 72-6. doi: 10.1016/j.toxrep.2017.01.001.

13. Guideline IH. Validation of analytical procedures: text and methodology. Q2 (R1) 2005; 1:1-5.

14. González AG, Herrador MÁ. A practical guide to analytical method validation, including measurement uncertainty and accuracy profiles. TrAC Trends in Analytical Chemistry 2007; 26(3): 227-38. doi: 10.1016/j.trac.2007.01.009.

15. Taverniers I, De Loose M, Van Bockstaele E. Trends in quality in the analytical laboratory. II. Analytical method validation and quality assurance. TrAC Trends in Analytical Chemistry 2004; 23(8): 535-52. doi: 10.1016/j. trac.2004.04.001.

16. Agbana BE, Joshua AO, Daikwo MA, Metiboba LO. Knowledge of occupational hazards among sawmill workers in Kwara state, Nigeria. Niger Postgrad Med J 2016; 23(1): 25-32. doi: 10.4103/1117-1936.180176.

17. Monger A, Wangdi K. Lead and mercury exposure and related health problems in metal artisan workplaces and high-risk household contacts in thimphu, Bhutan. ScientificWorldJournal 2020; 2020: 9267181. doi: 10.1155/2020/9267181.

18. Reich A, Wilke A, Gediga G, Baurecht H, Rodríguez E, Jakasa I, et al. Health education decreases incidence of hand eczema in metal work apprentices: results of a controlled intervention study. Contact Dermatitis 2020; 82(6): 350-60. doi: 10.1111/cod.13502.

19. Hänninen $H$, Eskelinen L, Husman K, Nurminen M. Behavioral effects of long-term exposure to a mixture of organic solvents. Scand J Work Environ Health 1976; 2(4): 240-55. doi: 10.5271/sjweh.2805.

20. Hane M, Axelson O, Blume J, Hogstedt C, Sundell L, Ydreborg B. Psychological function changes among house painters. Scand J Work Environ Health 1977; 3(2): 91-9. doi: $10.5271 /$ sjweh.2785.

21. Elofsson SA, Gamberale F, Hindmarsh T, Iregren A, Isaksson A, Johnsson I, et al. Exposure to organic solvents. A crosssectional epidemiologic investigation on occupationally exposed care and industrial spray painters with special reference to the nervous system. Scand J Work Environ Health 1980; 6(4): 239-73. doi: 10.5271/sjweh.2609.

22. Maizlish NA, Fine LJ, Albers JW, Whitehead L, Langolf GD. A neurological evaluation of workers exposed to mixtures of organic solvents. Br J Ind Med 1987; 44(1): 14-25. doi: 10.1136/oem.44.1.14.

23. Mergler D, Blain L, Lagacé JP. Solvent related colour vision 
loss: an indicator of neural damage? Int Arch Occup Environ Health 1987; 59(4): 313-21. doi: 10.1007/bf00405275.

24. Schwartz BS, Ford DP, Bolla KI, Agnew J, Rothman N, Bleecker ML. Solvent-associated decrements in olfactory function in paint manufacturing workers. Am J Ind Med 1990; 18(6): 697-706. doi: 10.1002/ajim.4700180608.

25. Bepko J, Mansalis K. Common occupational disorders: asthma, COPD, dermatitis, and musculoskeletal disorders. Am Fam Physician 2016; 93(12): 1000-6.

26. American Conference of Governmental Industrial Hygienists (ACGIH). Threshold Limit Values for Chemicaln Substances and Physical Agents and Biological Exposure Indices. USA: ACGIH; 2012.

27. Danadevi K, Rozati R, Reddy PP, Grover P. Semen quality of Indian welders occupationally exposed to nickel and chromium. Reprod Toxicol 2003; 17(4): 451-6. doi: 10.1016/ s0890-6238(03)00040-6.

28. Medeiros MG, Rodrigues AS, Batoréu MC, Laires A, Rueff J, Zhitkovich A. Elevated levels of DNA-protein crosslinks and micronuclei in peripheral lymphocytes of tannery workers exposed to trivalent chromium. Mutagenesis 2003; 18(1): 19-24. doi: 10.1093/mutage/18.1.19.

29. Danadevi K, Rozati R, Banu BS, Grover P. Genotoxic evaluation of welders occupationally exposed to chromium and nickel using the Comet and micronucleus assays. Mutagenesis 2004; 19(1): 35-41. doi: 10.1093/mutage/ geh001.

30. Li GJ, Zhang LL, Lu L, Wu P, Zheng W. Occupational exposure to welding fume among welders: alterations of manganese, iron, zinc, copper, and lead in body fluids and the oxidative stress status. J Occup Environ Med 2004; 46(3): 241-8. doi: 10.1097/01.jom.0000116900.49159.03.

31. Goulart M, Batoréu MC, Rodrigues AS, Laires A, Rueff J. Lipoperoxidation products and thiol antioxidants in chromium exposed workers. Mutagenesis 2005; 20(5): 3115. doi: 10.1093/mutage/gei043.

32. Popoola OE, Popoola AO, Purchase D. Levels of awareness and concentrations of heavy metals in the blood of electronic waste scavengers in Nigeria. J Health Pollut 2019; 9(21): 190311. doi: 10.5696/2156-9614-9.21.190311.

33. Crossgrove J, Zheng W. Manganese toxicity upon overexposure. NMR Biomed 2004; 17(8): 544-53. doi: $10.1002 / \mathrm{nbm} .931$.

34. Specht AJ, Dickerson AS, Kponee-Shovein KZ, Nkpaa KW, Weisskopf MG. Toenail metal exposures in fishermen from Bodo city, Nigeria. Bull Environ Contam Toxicol 2020;
104(1): 90-5. doi: 10.1007/s00128-019-02750-7.

35. Nriagu J, Afeiche M, Linder A, Arowolo T, Ana G, Sridhar $\mathrm{MK}$, et al. Lead poisoning associated with malaria in children of urban areas of Nigeria. Int J Hyg Environ Health 2008; 211(5-6): 591-605. doi: 10.1016/j.ijheh.2008.05.001.

36. Babalola OO, Ojo LO, Aderemi MO. Lead levels in some biological samples of auto-mechanics in Abeokuta, Nigeria. Indian J Biochem Biophys 2005; 42(6): 401-3.

37. Ademuyiwa O, Ugbaja RN, Idumebor F, Adebawo O. Plasma lipid profiles and risk of cardiovascular disease in occupational lead exposure in Abeokuta, Nigeria. Lipids Health Dis 2005; 4: 19. doi: 10.1186/1476-511x-4-19.

38. Orisakwe OE, Nwachukwu E, Osadolor HB, Afonne OJ, Okocha CE. Liver and kidney function tests amongst paint factory workers in Nkpor, Nigeria. Toxicol Ind Health 2007; 23(3): 161-5. doi: 10.1177/0748233707081908.

39. Osuntogun BA, Koku CA. Environmental-impacts of urban road transportation in South-western states of Nigeria. J Appl Sci 2007; 7(16): 2356-60. doi: 10.3923/ jas.2007.2356.2360.

40. Iarmarcovai G, Sari-Minodier I, Chaspoul F, Botta C, De Méo $\mathrm{M}$, Orsière $\mathrm{T}$, et al. Risk assessment of welders using analysis of eight metals by ICP-MS in blood and urine and DNA damage evaluation by the comet and micronucleus assays; influence of XRCC1 and XRCC3 polymorphisms. Mutagenesis 2005; 20(6): 425-32. doi: 10.1093/mutage/ gei058.

41. Botta C, Iarmarcovai G, Chaspoul F, Sari-Minodier I, Pompili J, Orsière T, et al. Assessment of occupational exposure to welding fumes by inductively coupled plasmamass spectroscopy and by the alkaline Comet assay. Environ Mol Mutagen 2006; 47(4): 284-95. doi: 10.1002/em.20205.

42. Batool M, Ahmad KS, Zahidqureshi, Mahboob N, Nimra. Determination of heavy metal toxicity in blood and health effect by AAS (detection of heavy metals and its toxicity in human blood). Archives of Nanomedicine: Open Access Journal 2018; 1(2): 22-8. doi: 10.32474/ anoaj.2018.01.000107.

43. Järup L, Bellander T, Hogstedt C, Spång G. Mortality and cancer incidence in Swedish battery workers exposed to cadmium and nickel. Occup Environ Med 1998; 55(11): 755-9. doi: 10.1136/oem.55.11.755.

44. Agency for Toxic Substances and Disease Registry (ATSDR). Toxicological Profile for Chromium. US: Department of Health and Human Services, Public Health Service; 2012. 